\title{
Influence of Fashion Behavior on Store Choice among the Arts College Students in Sivganga District
}

\author{
M. Faisal, S. Chandramohan, M. Ayisha Millath, AV.Karthick
}

\begin{abstract}
This article presents the impact of fashion trends for teenagers and its influence on store choice. The study was conducted with 300 teenagers of age between "18-25". Survey method with structured questionnaire is used to collect the data. Convenience sampling techniques were adopted and the data were collected from Sivaganga district of Tamil Nadu. The study resulted that, fashion related views and expectation varies with respect to area of Residence, Age, Family Income, Size of the family, and Frequency of purchase. Also, the most influencing sources for purchase is found to be comforted, moreover, it is also found that the influencing source also varies with respect to area of Residence, Age, Family Income, Size of the family, and frequency of purchase.
\end{abstract}

Keywords: expectations, fashion, sources, store choice, views.

\section{INTRODUCTION}

Recent years, the fashion store industry has turned out to be ever more competitive. One result has been the proliferation among scholars and professionals about how these organizations influence consumers' store choice conduct. In this paper propels the possibility that consumer shopping behavior which is a determinant of the store decision choice when stores offer diverse value designs. Thus, the study was conducted with a focus on fashion related views and expectation and how it varies with respect to area of Residence, Age, Family Income, Size of the family, and frequency of purchase. Also, the study was made to identify the most influencing sources for purchase and its impact with respect to area of Residence, Age, Family Income, Size of the family, and frequency of purchase.

Shopping constitutes a necessary and a routine form of consumer behavior. Not like most consumer shopping for contexts, the fashion garments and related products are characterized by (1) multiple shopping for goals that has to be achieved through the process of a fancy array of in-store stimuli akin to merchandise, brands, and point-of-purchase info, and (2) repetition at regular time intervals (e.g., once a week). These conditions produce a singular context during

Revised Manuscript Received on July 22, 2019.

M. Faisal, Research Scholar, Alagappa Institute of Management, Alagappa University, Karaikudi, India, Email: faisalfais.m@gmail.com

Dr. S. Chandramohan, Professor, Alagappa Institute of Management, Alagappa University, Karaikudi, India, Email :lathamohan_sibi@yahoo.co.in.

Dr.M.AyishaMillath, Assistant Professor, Alagappa Institute of Management, Alagappa University, Karaikudi, India, Email: ayishamillath05@gmail.com.

AV.Karthick, Research Scholar, Alagappa Institute of Management, Alagappa University, Karaikudi, India, Email: avkarthick@ gmail.com which purchase intentions and outcomes typically differ on a range of situational factors. Analysis on in-store consumer behavior has centered totally on the concerns on in-store display arrangements. A related, nonetheless, completely different, stream of analysis has centered on factors that designate unplanned shopping of fashionable garments and products, the kind of store and products, the quantity and frequency of purchase, and shopper demographic characteristics. The study was conducted with 300 teenagers of age between "18-25". Survey method with a structured questionnaire to collect the data. Convenience sampling techniques were adopted and the data were collected from Sivaganga district of Tamil Nadu.

\section{REVIEW OF LITERATURE}

Shopping pattern have been appearing to be a key concept to support look into for the researcher for decades (Darden W. R., 1980), and the significance of shopping pattern by and large models of support conduct is all around recorded in (Darden W. R., 1987). (Pessemier, 1980)used shopping pattern as a key component in displaying store picture and position. Shopping patterns have been appeared to be firmly identified with affecting components, for example, consolidate in the family life cycle, psychographic qualities, and statistic information. Analysts have exhibited that the phases of the family life cycle essentially impact the purchaser's shopping orientation (Wells, 1967). As the family advances through the stages, new circumstances and issues are introduced. Changes can incorporate the accessibility of assets, for example, time and cash, the quantity of individuals in the family, and the times of every part.

Stage in the family life cycle, area of residence and financial status are critical determinants of customers buying behavior. In any case, annual family salary alone isn't adequate to clarify accommodation introduction. The shopping introduction of the elderly contrasts from that of more teenagers (Lumpkin, Shopping orientation segmentation of the elderly consumer., 1985).

(Bellenger, 1977)suggested the connection between shopping introductions and store qualities. They found that the leisure customer sets an abnormal state of significance on store properties, for example, store, stylistic theme, assortment of item, and quality. (Lumpkin, Shopping orientation segmentation of the elderly consumer, 1985)researched connections among the elderly's shopping introductions, the significance of store/item traits, data sources utilized, and support inclinations. The three shopping introduction bunches were recognized by their utilization of data from clothing shopping and the significance of 
store properties yet were not diverse in their support conduct. Shopping introductions impact both the particular retail outlet and the general sort of outlet chose (Hawkins, 1989). For instance, buyers' shopping introduction was a solid indicator of both individual store and store-type decision conduct (Darden W. R., 1987). Recreational and monetary customers were found to show diverse wants with respect to strip mall choice (Bellenger et al., 1977). For example, the leisure customer favored a top notch focus which offered broad assortment and an expansive number of related administrations while the comfort or financial customer was principally worried about low costs.

\section{OBJECTIVES OF THE STUDY}

$>$ To understand the fashion related views and expectations among the Arts college students

$>$ To elucidate the influencing sources for the fashion behavior of the students.

$>$ To find out the store choice for garments and fashion products by the respondents.

$>$ To analyse the reasons for the store choice

$>$ To offer suggestions to the Fashion Retailers based on the findings.

\section{ANALYSIS AND INTERPRETATION}

\section{DESCRIPTIVE STATISTICS}

Table 1 - Descriptive statistics to with respect to fashion related views and expectations

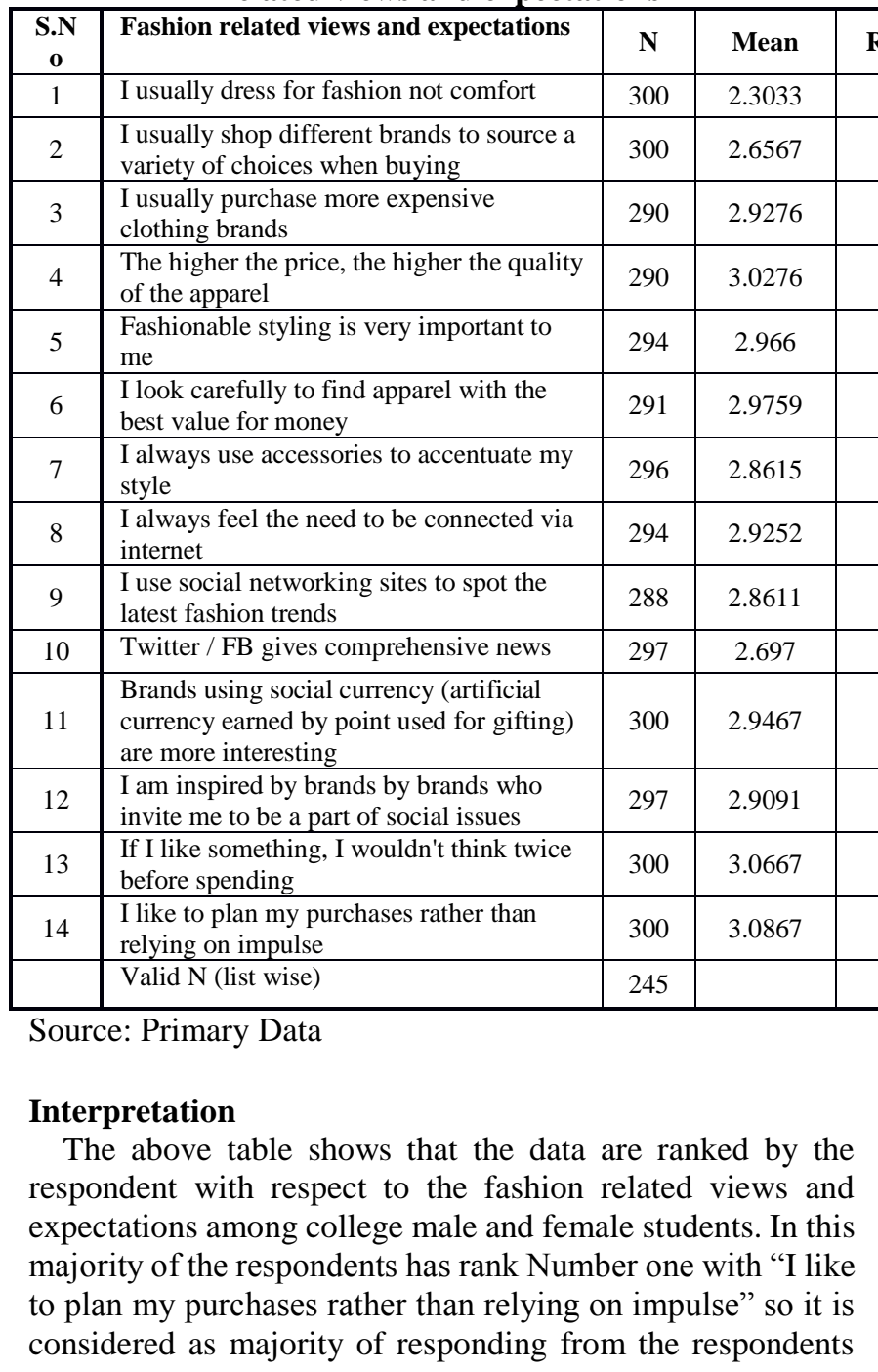

and it is ranked as Number One and the minimum responds from the respondents for "I usually dress for fashion not comfort" so it is considered as least and ranked as Number 14.

\section{ANOVA TEST}

\section{ANOVA test - Fashion related views Expectations Vs}

\section{Residence}

Null hypothesis H0- There is no significant difference between the Fashion related views Expectations Vs Residence.

The alternate hypothesis H1-There is a significant difference between the Fashion related views Expectations Vs Residence.

\section{Table 2 -ANOVA test - Fashion related views \& Expectations Vs Place of Residence}

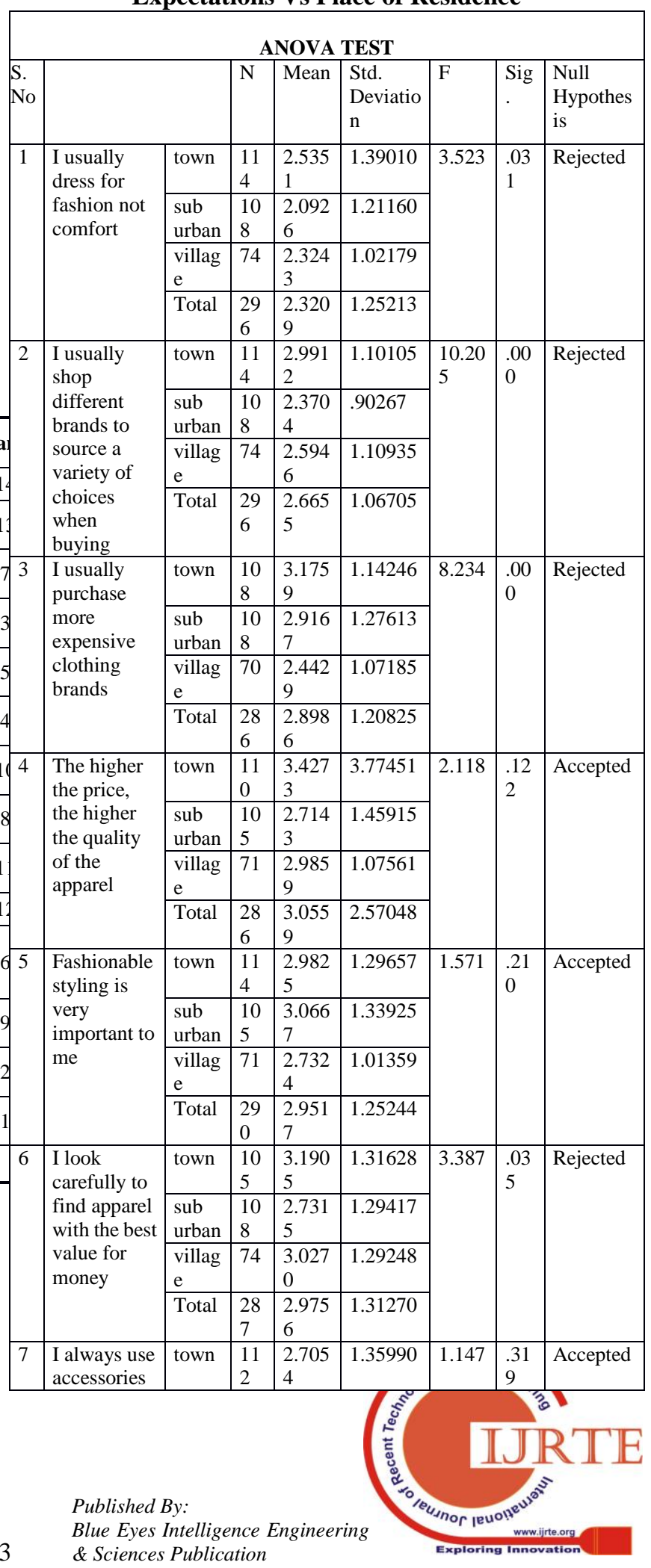




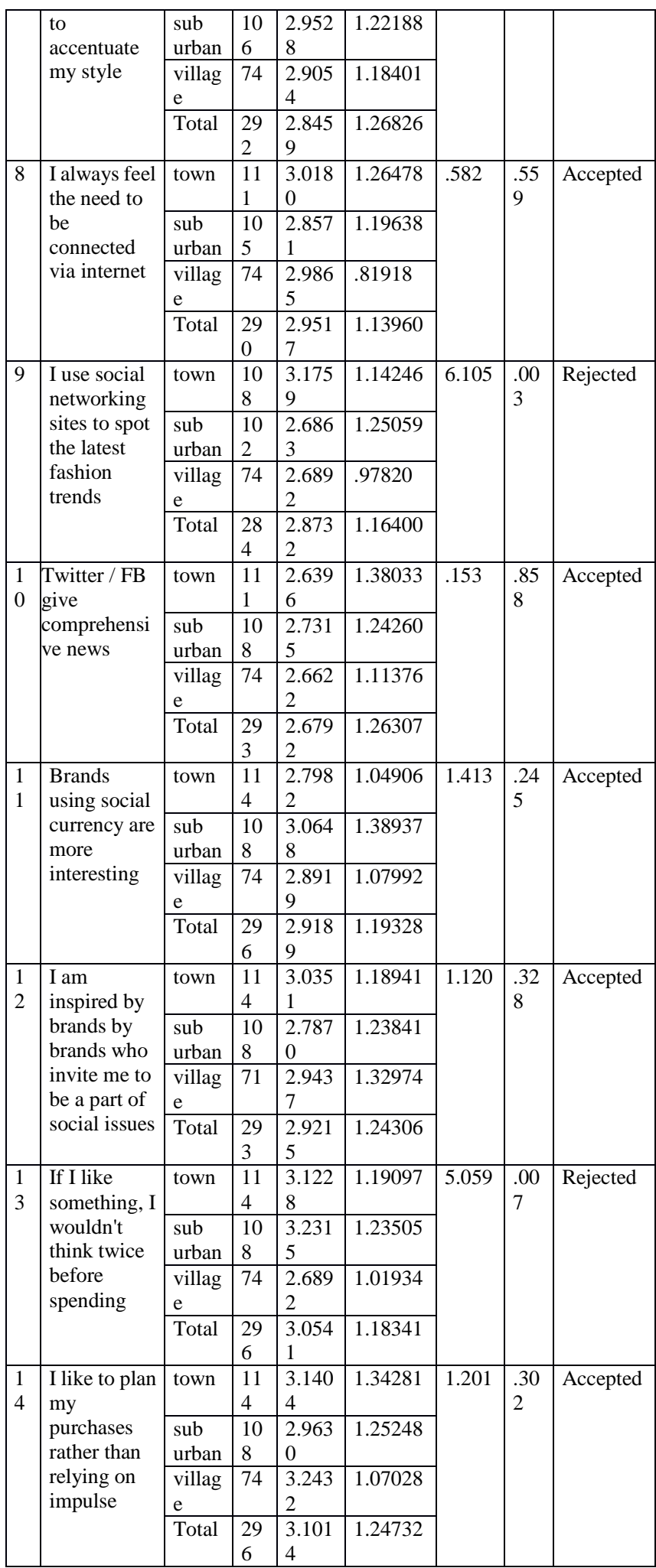

Source: Primary Data

\section{Interpretation}

Based on the result generated by SPSS, the significant value is lower than 0.05 for variable $1,2,3,6,9$ and 13. So reject null hypothesis. Hence there is a significance difference in the in opinion on before mentioned Fashion related views Expectations with respect to place of Residence.

While rest of the significant value is greater than 0.05 for rest of the functionality variables, hence, accept null hypothesis. There is no significant difference in opinion with other Fashion related views Expectations with respect to place of Residence.

\section{CORRELATION ANALYSIS}

Correlation analysis with respect to Age, Family Income, Size of the family, frequency of purchase and Fashion related views \& Expectations

Null hypothesis H0- There is no significant relationship between considered variables

Alternate hypothesis H1-There is significant relationship between considered variables

Table 3 - Correlation analysis with respect to Age, Family Income, Size of the family, frequency of purchase and Fashion related views \& Expectations

\begin{tabular}{|l|l|l|l|l|l|}
\hline \multicolumn{2}{|c|}{} & Age & $\begin{array}{l}\text { Family } \\
\text { Income }\end{array}$ & $\begin{array}{l}\text { Size of } \\
\text { the } \\
\text { family }\end{array}$ & $\begin{array}{l}\text { Frequency } \\
\text { of purchase }\end{array}$ \\
\hline $\begin{array}{l}\text { Fashion related } \\
\text { views } \\
\text { Expectations }\end{array}$ & $\begin{array}{l}\text { Pearson } \\
\text { Corre }\end{array}$ & -.111 & $.173^{* *}$ & .050 & .055 \\
\cline { 2 - 6 } & $\begin{array}{l}\text { Sig. } \\
\text { (2-tailed) }\end{array}$ & .083 & .006 & .439 & .392 \\
\cline { 2 - 6 } & $\mathrm{N}$ & 245 & 245 & 245 & 245 \\
\hline
\end{tabular}

Source: Primary Data

\section{Interpretation}

The calculated significance value is .006 , which is less than .05 for family income, hence null hypothesis rejected. Thereby there is significant positive relationship between various Family income and fashion related views and expectations.

While other variables doesn't have significant relationship with the fashion related views and expectation factor.

\section{ANOVA TEST}

ANOVA test -Influencing Source Vs Place of Residence Null hypothesis H0- There is no significant difference between the Influencing Source Vs Place of Residence.

Alternate hypothesis H1-There is significant difference between the Influencing Source Vs Place of Residence.

\section{Table 4 -ANOVA test - Influencing Source Vs Place of} Residence

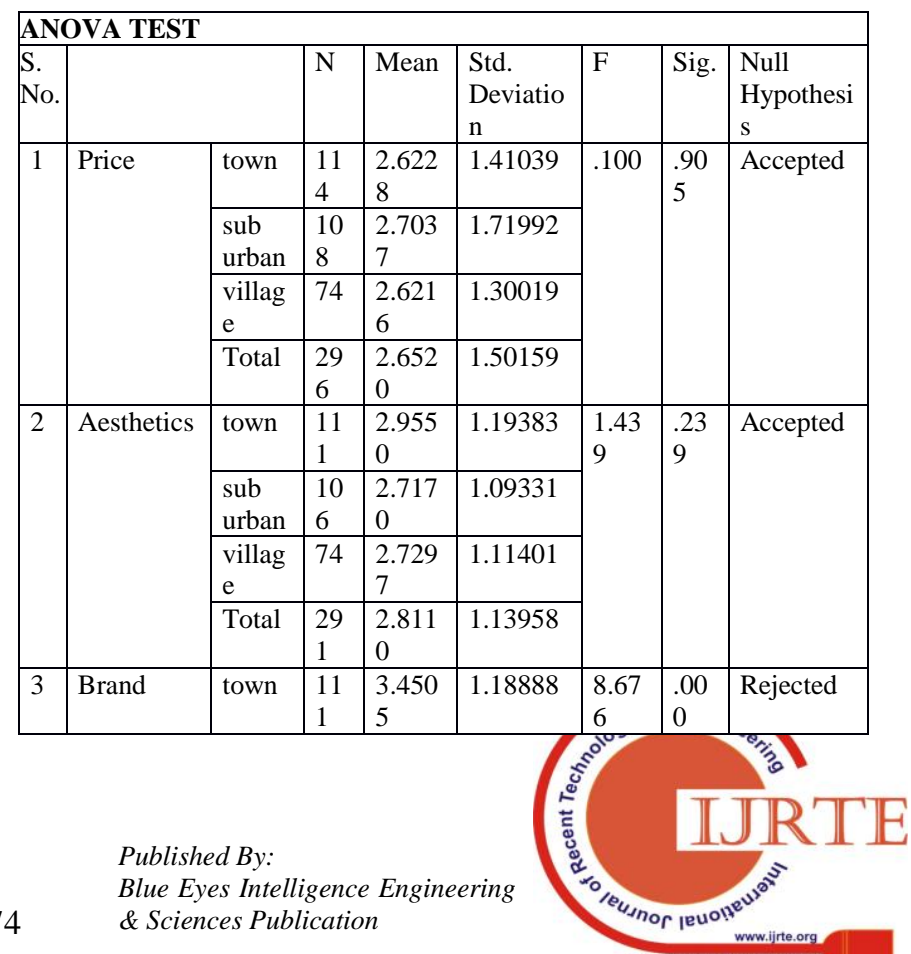




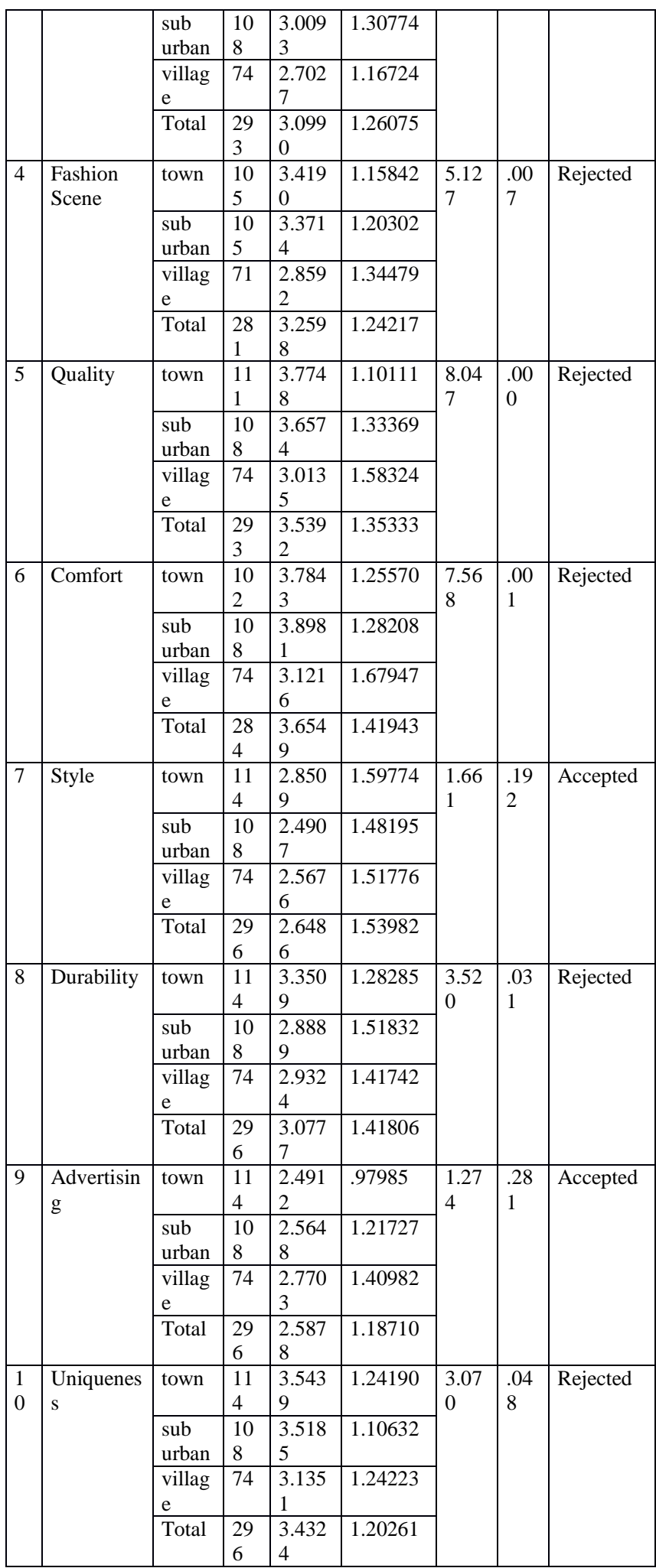

Source: Primary Data

\section{Interpretation}

Based on the result generated by SPSS, the significant value is lower than 0.05 for variable $3,4,5,6,8$ and 10. So reject null hypothesis. Hence there is a significance difference in the in opinion on before mentionedInfluencing Sourcewith respect to place of Residence.

While rest of the significant value is greater than 0.05 for rest of the functionality variables, hence, accept null hypothesis. There is no significant difference in opinion with other Influencing Source with respect to place of Residence.
CORRELATION TEST

Correlation analysis with respect to Age, Family Income, Size of the family, frequency of purchase and Influencing Source

Null hypothesis H0- There is no significant relationship between considered variables

Alternate hypothesis H1-There is significant relationship between considered variables

Table 5 - Correlation analysis with respect to Age, Family Income, Size of the family, frequency of purchase and Influencing Source

\begin{tabular}{|l|l|r|r|r|r|}
\hline \multicolumn{2}{|c|}{} & Age & \multicolumn{1}{c|}{$\begin{array}{c}\text { Family } \\
\text { Income }\end{array}$} & $\begin{array}{c}\text { Size of } \\
\text { the } \\
\text { family }\end{array}$ & $\begin{array}{c}\text { Frequency } \\
\text { of purchase }\end{array}$ \\
\hline $\begin{array}{l}\text { Influencing } \\
\text { Source }\end{array}$ & $\begin{array}{l}\text { Pearson } \\
\text { Correlation }\end{array}$ & $-.207^{* *}$ & $.241^{* *}$ & -.085 & .055 \\
\cline { 2 - 7 } & $\begin{array}{l}\text { Sig. } \\
(2-\text {-tailed })\end{array}$ & .001 & .000 & .170 & .370 \\
\cline { 2 - 7 } & $\mathrm{N}$ & 265 & 265 & 265 & 265 \\
\hline
\end{tabular}

Source: Primary Data

\section{Interpretation}

The calculated significance value for age and family income is calculated to be .001 and .000 , hence null hypothesis rejected. Thereby there is significant negative relationship between age and influencing source. While, there is significant positive relationship between various Family income and influencing source. While other variables doesn't have significant relationship with fashion related to views and expectations factor.

\section{DESCRIPTIVE STATISTICS}

Table 6 - Descriptive statistics on Store choice for garments and fashion products

\begin{tabular}{|c|c|c|c|c|c|c|c|c|}
\hline \multicolumn{9}{|c|}{ Descriptive Statistics } \\
\hline & & $\begin{array}{l}\text { Bag } \\
\text { s / } \\
\text { Wal } \\
\text { lets }\end{array}$ & Belts & $\begin{array}{l}\text { Artificia } \\
1 \\
\text { Jeweller } \\
y\end{array}$ & $\begin{array}{l}\text { Hats } \\
\text { / } \\
\text { Cap } \\
\text { s }\end{array}$ & $\begin{array}{l}\text { Watch } \\
\text { es }\end{array}$ & $\begin{array}{l}\text { Sun } \\
\text { glas } \\
\text { ses }\end{array}$ & $\begin{array}{l}\text { Clothi } \\
\text { ng's }\end{array}$ \\
\hline \multirow[t]{2}{*}{$\mathrm{N}$} & Valid & 300 & 297 & 294 & 300 & 291 & 290 & 300 \\
\hline & Missing & 0 & 3 & 6 & 0 & 9 & 10 & 0 \\
\hline \multicolumn{2}{|c|}{ Mean } & $\begin{array}{l}2.12 \\
33\end{array}$ & $\begin{array}{l}2.629 \\
6\end{array}$ & 2.7313 & $\begin{array}{l}2.88 \\
00\end{array}$ & $\begin{array}{l}3.216 \\
5\end{array}$ & $\begin{array}{l}3.03 \\
10\end{array}$ & $\begin{array}{l}3.070 \\
0\end{array}$ \\
\hline \multicolumn{2}{|c|}{ Mode } & 1.00 & $2.00^{\mathrm{a}}$ & 3.00 & 2.00 & 3.00 & 3.00 & 3.00 \\
\hline \multicolumn{2}{|c|}{$\begin{array}{l}\text { Respective } \\
\text { Option }\end{array}$} & $\begin{array}{l}\text { Mal } \\
\text { ls }\end{array}$ & Street & Shops & $\begin{array}{l}\text { Stre } \\
\text { et }\end{array}$ & Shops & $\begin{array}{l}\text { Sho } \\
\text { ps }\end{array}$ & Shops \\
\hline
\end{tabular}

Source: Primary Data

\section{Interpretation}

The above table shows that the store choice of the respondent for garments and fashion products majority of the respondent for bags in mall is 2.1233 is the mean and belt is 2.6296 and jewellery is 2.7313 , hats is 2.8800 , watches 3.2165 , sun glasses 3.0310 and clothing 3.0700 in this majority of respondent preferring shops for purchasing the watch, sunglasses and clothing's. 


\section{Descriptive statistics}

Table 7 - Descriptive statistics to identify the Reason for the store choice

\begin{tabular}{|l|l|l|l|}
\hline Reason for the store choice & N & Mean & Rank \\
\hline Wide range of collections & 300 & 5.67 & 7 \\
\hline Display & 300 & 5.7267 & 8 \\
\hline Price & 300 & 4.3833 & 1 \\
\hline Brand image & 300 & 5.2833 & 3 \\
\hline Peer suggestion & 300 & 5.2967 & 4 \\
\hline Location of the store & 300 & 5.1767 & 2 \\
\hline Offers and discounts & 300 & 5.3967 & 5 \\
\hline Impulse & 300 & 5.96 & 9 \\
\hline Family Suggestion & 300 & 5.6467 & 6 \\
\hline Service by the store staff & 300 & 6.2467 & 10 \\
\hline
\end{tabular}

Source: Primary Data

\section{Interpretation}

The above table shows that the reason for the store choice with the various factors are listed and ranked by the respondent. The majority of the respondent is with the highest rank of Price so the majority for Price is Rank ONE and the least is Service by the store staff.

\section{FINDINGS AND DISCUSSION}

From the above analysis the researcher identified thatplan my purchases followed by I wouldn't think twice before spending. The significance difference in the opinion on before mentioned Fashion related to views Expectation with respect to place of Residence. There is significant positive relationship between various Family income and fashion related views and expectations.

\section{CONCLUSION}

The analyses on fashion related views and expectations illustrated that, the consumers are planning their purchase rather than relying on their impulse also it is found that financial constraints plays a major role in consumer buying behavior. Through the analysis made to it can be seen that the area of residence of the consumer significantly influent the fashion related views and expectations for most of the considered variables. Furthermore, family income was found to be significantly influence the fashion related views and expectations. The rank test performed on most influencing source illustrated that comfort, quality and advertisement to be the major influencing variables. It can be seen that the area of residence of the consumer significantly influencing their store choice behavior. Furthermore, age and family income was found to be significantly being an influencing source. Through the study it was found that it is the price, location of the store and brand image majorly contributes to store choice.

\section{REFERENCES}

1. Bellenger, D. N. (1977). Shopping center patronage motives. . Journal of Retailing , (52)3, 29-38.

2. Darden, W. R. (1980). A patronage model of consumer behavior. In R. W. Stampfl \& E. Hirschman (Eds.), Competitive structure in retail markets: The department store perspective. Chicago: American Marketing Association, (pp. 43-52).
3. Darden, W. R. (1987). Socialization effects of retail work experience on shopping orientations. Academy of Marketing, 15 52-63.

4. Hawkins, D. I. (1989). Consumer behavior (4th ed.). . Homewood, IL: Irwin.

5. Lumpkin, J. R. (1985). Shopping orientation segmentation of the elderly consumer. Journal of the Academy of Marketing Science , 13 272-289.

6. Lumpkin, J. R. (1985). Shopping orientation segmentation of the elderly consumer. . Journal of the Academy of Marketing Science , 13 272-289.

7. Pessemier, E. A. (1980). Store image and positioning. Journal of Retailing , (51)6, 94-106

8. Wells, W. D. (1967). Life cycle concept in marketing research. Journal of Marketing Research , 3(4), 355-363.

9. Margaret Bruce, Lucy Daly, (2006) "Buyer behaviour for fast fashion", Journal of Fashion Marketing and Management: An International Journal, Vol. 10 Issue: 3, pp.329-344.

10. Martin Evans, (1989) "Consumer Behaviour towards Fashion", European Journal of Marketing, Vol. 23 Issue: 7, pp.7-16.

11. Constanza Bianchi \& Grete Birtwistle (2010) Sell, give away, or donate: an exploratory study of fashion clothing disposal behaviour in two countries, The International Review of Retail, Distribution and Consumer Research, 20:3, 353-368.

12. Richard Michon, Hong Yu, Donna Smith, Jean- Charles Chebat, (2008) "The influence of mall environment on female fashion shoppers' value and behaviour", Journal of Fashion Marketing and Management: An International Journal, Vol. 12 Issue: 4, pp.456-468.

13. Helen McCormick, Charlotte Livett, (2012) "Analysing the influence of the presentation of fashion garments on young consumers' online behaviour", Journal of Fashion Marketing and Management: An International Journal, Vol. 16 Issue: 1, pp.21-41.

14. Alana M James, Lizette Reitsma \& Mersha Aftab (2019) Bridging the doublegap in circularity. Addressing the intention-behaviour disparity in fashion, The Design Journal, pp. 901-914.

15. Lewis, C., Kerr, G. \& Burgess, L. (2019). Positioning a destination as fashionable: The destination fashion conditioning framework. Tourism Management: research, policies, practice, 72 209-219.

16. Ju Yeun Jang, Eunsoo Baek, Ho Jung Choo, (2018) "Managing the visual environment of a fashion store: Effects of visual complexity and order on sensation-seeking consumers", International Journal of Retail \& Distribution Management, Vol. 46 Issue: 2, pp.210-226.

17. Emel Yarimoglu and Gul Binboga (2018). Understanding sustainable consumption in an emerging country: The antecedents and consequences of the ecologically conscious consumer behavior model, Business Strategy and the Environment, 28, 4, (642-651) 